AKSIOMA: Jurnal Program Studi Pendidikan Matematika

DOI: https://doi.org/10.24127/ajpm.v10i4.3929

\title{
ANALISIS KEMAMPUAN KOMUNIKASI MATEMATIKA SISWA PADA MATERI PRISMA DAN LIMAS
}

\author{
Zharifatul Aqilah $^{1}$, Kartini ${ }^{2 *}$ \\ 1,2* Program Studi Pendidikan Matematika, Fakultas Keguruan dan Ilmu Pendidikan, \\ Universitas Riau, Pekanbaru, Riau, Indonesia \\ *Corresponding author. Pekanbaru, Indonesia. \\ E-mail: $\quad$ zharifatul.aqilah7414@ grad.unri.ac.id ${ }^{1)}$ \\ $\underline{\text { kartini@lecturer.unri.ac.id }}^{\left.2^{*}\right)}$
}

Received 06 July 2021; Received in revised form 23 Novebmber 2021; Accepted 15 December 2021

\begin{abstract}
Abstrak
Komunikasi matematika merupakan kemampuan yang harus dikembangkan dalam pembelajaran matematika. Tanpa komunikasi dalam matematika, maka hanya akan ada sedikit keterangan, data, dan fakta dalam melakukan proses dan aplikasi matematika. Penelitian ini bertujuan untuk mendeskripsikan kesalahan siswa pada setiap indikator kemampuan komunikasi matematika dengan subjek siswa kelas VIII MTs Negeri Karimun sebanyak 16 orang. Penelitian ini menggunakan pendekatan deskriptif kualitatif yang mendeskripsikan kesalahan siswa dalam menyelesaikan soal prisma dan limas Data dari hasil tes yang dilakukan yaitu berupa hasil belajar siswa yang pengumpulan datanya menggunakan instrumen berupa tes uraian. Berdasarkan hasil analisis data berupa hasil tes yang diberikan kepada siswa dapat ditarik kesimpulan bahwa letak kesalahan siswa pada kemampuan komunikasi matematika dalam menyelesaikan soal-soal prisma dan limas yaitu (1) kesalahan dalam memahami representasi gambar; (2) kesalahan dalam memahami makna dari gambar; dan (3) kesalahan prosedur tidak tepat.
\end{abstract}

Kata Kunci: Analisis; kesalahan; komunikasi matematika.

\begin{abstract}
Mathematical communication is an ability that must be developed in learning mathematics. Without communication in mathematics, there will be little information, data, and facts in carrying out mathematical processes and applications. This study aims to describe students' errors in each indicator of mathematical communication skills with 16 students as the subject of class VIII MTs Negeri Karimun. This study uses a qualitative descriptive approach that describes students' errors in solving prism questions and five. Data from the test results in the form of student learning outcomes were collected using an instrument in the form of a description test. Based on data analysis in the form of test results given to students, it can be concluded that students' errors in mathematical communication skills in solving prism and five problems are (1) errors in understanding image representation; (2) errors in understanding the meaning of the picture; and (3) improper procedural error.
\end{abstract}

Keywords: Analysis; error; mathematical communication.

This is an open-access article under the Creative Commons Attribution 4.0 International License

\section{PENDAHULUAN}

Komunikasi merupakan salah satu bagian penting dalam matematika karena merupakan cara berbagi ide dan memperjelas pemahaman (Arifin et al., 2016). Dengan komunikasi, siswa dapat bertukar ide, baik di antar siswa sendiri maupun di antara siswa dengan guru dan lingkungannya. Jadi jelaslah bahwa komunikasi matematika merupakan kemampuan yang harus dikembangkan dalam pembelajaran matematika. Kemampuan komunikasi merupakan kemampuan dasar yang harus dimiliki oleh siswa (Noor Ariani, 2017). Pentingnya kemampuan komunikasi 
dapat dilihat dalam Permendiknas Nomor 22 Tahun 2016, yaitu siswa dapat memecahkan suatu permasalahan atau memperjelas keadaan dengan mengomunikasikan simbol, tabel, grafik, atau diagram untuk menyampaikan gagasan (Rizta \& Antari, 2018). Tanpa komunikasi dalam matematika, maka hanya akan ada sedikit keterangan, data, dan fakta dalam melakukan proses dan aplikasi matematika (Fadilah \& Amalia, 2020).

Melakukan komunikasi dalam matematika bukan hal yang mudah. Kemampuan komunikasi matematika dapat dilihat dari bagaimana siswa menghubungkan kasus dengan model matematika dan menjelaskan penyelesaiannya menggunakan bahasa yang efektif (Mawaddah \& Mahmudi, 2021). Kemampuan komunikasi matematis meliputi kemampuan siswa dalam menyampaikan ide matematika. Ide matematika tersebut dapat secara lisan maupun tulisan yang bisa dikembangkan melalui proses pembelajaran matematika (Prentha et al., 2021). Dengan menggunakan komunikasi matematika, siswa dapat mengorganisasi berfikir matematisnya.

Proses pembelajaran digunakan untuk memfasilitasi kemampuan komunikasi matematis dalam mengkomunikasikan ide-ide matematis, menyampaikan proses dan hasil pemecahan masalah dapat mengembangkan kemampuan berfikir matematis tingkat tinggi seperti logis, analitis, sistematis, kritis, kreatif dan produktif secara maksimal (Noor Ariani, 2017). Oleh karena itu perlu adanya proses pembelajaran yang memfasilitasi kemampuan komunikasi matematis, dimana kemampuan komunikasi matematis dapat dilihat dari bagaimana siswa menyampaikan ide matematis melalui representasi kata, gambar, angka, simbol/notasi dengan benar (Mawaddah \& Mahmudi, 2021),

Kemampuan komunikasi matematis merupakan kemampuan yang perlu ditingkatkan karena berdasarkan penelitian yang dilakukan sebelumnya, diantaranya; 1) (Aminah et al., 2018), menyimpulkan bahwa tingkat kemampuan komunikasi matematis siswa masih tergolong rendah. Siswa masih merasa kesulitan dalam menyelesaikan soal jenis kemampuan komunikasi matematika. 2) (Mustika, 2018) dalam kesimpulan peneliti menyampaikan bahwa tingkat kemampuan komunikasi matematis siswa masih tergolong rendah, terutama pada indikator menjelaskan ide, situasi dan relasi matematika ke dalam bentuk gambar, grafik dan aljabar, menyatakan peristiwa sehari-hari dalam bahasa atau simbol matematika, dan membaca presentasi matematika tertulis dan menyusun pertanyaan yang relevan.

Siswa yang memiliki komunikasi matematis dapat mengkomunikasikan ide-ide matematisnya kepada orang lain sehingga dapat meningkatkan pemahaman matematisnya (Susanti \& Ashari, 2019). Kesulitan yang dialami siswa dapat menimbulkan kesalahan sewaktu menjawab soal tes. Kesalahan yang dilakukan siswa dalam menjawab persoalan matematika menunjukkan adanya kesulitan yang dialami oleh siswa pada mata pelajaran matematika (Syahrir et al., 2013).

Analisis kesalahan dapat membantu guru dalam menerapkan pendekatan, model dan metode belajar yang tepat agar dapat menciptakan suasana belajar yang optimal dan tujuan pembelajaran dapat tercapai (Septiani et al., 2020). Maka perlu dilakukan analisis kesalahan pada tes kemampuan komunikasi matematika siswa. Berdasarkan uraian tersebut, tujuan dari 
penelitian ini adalah untuk melihat letak kesalahan siswa pada kemampuan komunikasi matematika dalam menyelesaikan soal-soal prisma dan limas.

\section{METODE PENELITIAN}

Penelitian ini menggunakan pendekatan kualitatif deskriptif dengan tujuan untuk menganalisis kemampuan komunikasi matematika siswa. Penelitian ini dilakukan di MTs Negeri Karimun dengan subjek yang digunakan dalam penelitian ini adalah siswa kelas VIII yang berjumlah 16 orang. Objek penelitian yang digunakan adalah analisis kemampuan komunikasi matematika siswa pada materi prisma dan limas. Penelitian dilakukan pada tanggal 28 April 2021.

Instrumen yang digunakan adalah instrument tes yaitu menggunakan instrumen soal tes essay untuk melihat kemampuan komunikasi matematika siswa. Lembar tes disusun dalam beberapa butir soal essay untuk melihat kemampuan komunikasi matematis siswa. Instrumen yang digunakan pada penelitian ini yaitu kisi-kisi soal, kartu soal, dan rubrik penilaian.
Instrumen dapat digunakan jika nilai validitas, reliabilitas, dan daya pembedanya terpenuhi (Syahrir et al., 2013). Instrumen dikatakan valid jika taraf signifikan $(\alpha) \quad 5 \%$. Sedangkan instrumen yang tidak memenuhi kriteria valid, maka instrument tersebut tidak akan digunakan (Lusiana et al., 2019). Soal yang sudah valid, selanjutnya dilakukan uji reliabilitas dengan menggunakan rumus Alpha. Instrumen yang memperoleh angka korelasinya diatas 0,60 dan kurang dari 1, maka instrumen tersebut memiliki korelasi tinggi atau reliabel, sedangkan apabila angka korelasinya di bawah 0,50 , maka instrumen tersebut berkorelasi rendah atau tidak reliabel (Lusiana et al., 2019).

Tolak ukur untuk menginterpretasikan taraf kesukaran tiap butir soal menggunakan kriteria sukar dengan indeks $\quad 0.00-0.30$, kriteria sedang dengan indeks 0.31 - 0.70 , dan kriteria mudah dengan indeks 0,71-1,00 (Arikunto, 2015). Berdasarkan perhitungan pada instrument tes kemampuan komunikasi matematis, diperoleh validitas, realibilitas, daya pembeda, dan tingkat kesukaran yang disajikan dalam Tabel 1.

Tabel 1. Rekapitulasi hasil uji instrumen

\begin{tabular}{ccccccccc}
\hline \multirow{2}{*}{$\begin{array}{c}\text { No Butir } \\
\text { Soal }\end{array}$} & \multicolumn{2}{c}{ Validitas } & \multicolumn{2}{c}{ Realibilitas } & \multicolumn{2}{c}{ Daya Pembeda } & \multicolumn{2}{c}{ Tingkat Kesukaran } \\
\cline { 2 - 8 } & $\boldsymbol{r}_{\boldsymbol{x y}}$ & Interpretasi & $\boldsymbol{r}$ & Interpretasi & DP & Interpretasi & TK & Interpretasi \\
\hline 1 & 0,708 & Tinggi & & & 0,481 & Baik & 0,759 & Sedang \\
2 & 0,635 & Tinggi & 0,635 & Tinggi & 0,296 & Cukup & 0,852 & Mudah \\
3 & 0,603 & Tinggi & & & 0,370 & Cukup & 0,556 & Sedang \\
\hline
\end{tabular}

Berdasarkan hasil perhitungan validitas dan reliabilitas intrumen tes yang dilakukan (Tabel 1), diperoleh kesimpulan bahwa instrumen soal kemampuan komunikasi matematis valid dan reliabel, sehingga instrument tes dapat digunakan.

Kemampuan komunikasi matematika siswa dalam penelitian ini dideskripsikan berdasarkan tiga indikator.
Indikator yang digunakan yaitu (1) Kemampuan membaca representasi matematis dan menyelesaikannya; (2) Kemampuan menyatakan gambar atau benda nyata ke dalam matematika dan menyelesai-kannya; (3) Kemampuan mengekspresi-kan peristiwa sehari-hari ke dalam bahasa matematika dan menyelesaikannya. 


\section{Soal 1}

Jika diketahui luas permukaan kubus $1176 \mathrm{~cm}^{2}$

Tentukan volume bangunan di samping!

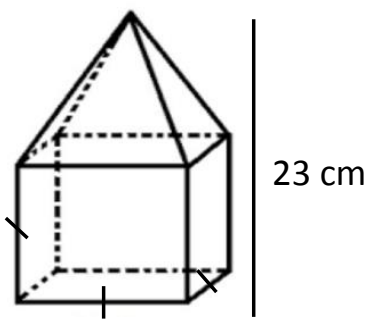

Soal 2

Sari ingin membungkus 20 buah coklat yang telah dibuatnya seperti gambar di samping. Jika diketahui lebar coklat 6 $\mathrm{cm}$, tinggi $4 \mathrm{~cm}$, dan panjang coklat 15

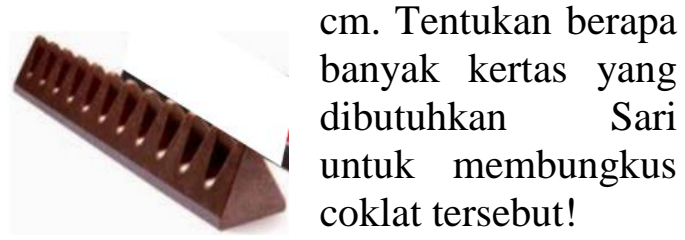

Soal 3

Hani membuat kue yang dimasukkan ke dalam wadah yang berbentuk limas dengan alas berbentuk persegi dan keliling alas $40 \mathrm{~cm}$, panjang sisi tegak $13 \mathrm{~cm}$. Gambarkan wadah coklat dan tentukan luas permukaan wadah tersebut!

Data dari hasil tes yang dilakukan yaitu berupa hasil belajar siswa yang pengumpulan datanya menggunakan instrumen berupa tes uraian sebanyak 3 butir soal. Data yang telah didapat akan diolah dengan menghubungkan nilai atau angka yang dapat dihitung secara sistematis menggunakan perhitungan statistika.

Analisis data yang digunakan dalam penelitian ini adalah dengan cara mereduksi data, penyajian data, dan kesimpulan.

a. Reduksi data

Mereduksi data dalam penelitian ini yaitu untuk mengetahui dan menjelaskan letak kesalahan siswa dalam menyelesaikan soal ditinjau dari indikator kemampuan komunikasi matematis.

\section{b. Penyajian Data}

Penyajian data dalam penelitian ini berupa hasil tes yang diberikan. Kesalahan-kesalahan yang dilakukan oleh siswa kemudian dicatat dan dikualifikasikan berdasarkan letak kesalahannya. Kesalahan siswa berdasarkan hasil jawaban pada lembar jawaban siswa akan dihitung persentase indikator setiap bentuk kesalahan.

c. Menarik kesimpulan

Dengan menganalisis data yang diperoleh dari hasil tes, jawaban siswa dapat ditarik kesimpulan apa saja kesalahan dalam menyelesaikan soal essay materi prisma dan limas. Analisis data kesalahan siswa dilakukan untuk meningkatkan kemampuan komunikasi matematis siswa.

\section{HASIL DAN PEMBAHASAN}

Komunikasi menjadi fokus utama dalam menilai kemampuan komunikasi matematis siswa. Berdasarkan hasil analisis terhadap jawaban siswa dalam mengerjakan soal kemampuan komunikasi matematis didapatkan bahwa kemampuan komunikasi pada tiap indikator tergolong sedang hingga tinggi. Kategori kemampuan komunikasi matematis siswa disajikan pada Tabel 2 dan besaran persentase tiap indikator disajikan pada Tabel 3.

Tabel 2. Kategori kemampuan komunikasi matematis

\begin{tabular}{cc}
\hline Kategori & $\begin{array}{c}\text { Kemampuan Komunikasi } \\
\text { Matematis }\end{array}$ \\
\hline Tinggi & $67 \%-100 \%$ \\
Sedang & $34 \%-66 \%$ \\
Rendah & $0-33 \%$ \\
\hline Sumber: (Septiani et al., 2020)
\end{tabular}


DOI: https://doi.org/10.24127/ajpm.v10i4.3929

Tabel 3. Persentase kemampuan komunikasi matematis

\begin{tabular}{lc}
\hline $\begin{array}{l}\text { Indikator Kemampuan } \\
\text { Komunikasi Matematis }\end{array}$ & Persentase \\
\hline $\begin{array}{l}\text { Kemampuan membaca } \\
\text { representasi matematis dan } \\
\text { menyelesaikannya }\end{array}$ & $64,06 \%$ \\
$\begin{array}{l}\text { Kemampuan menyatakan } \\
\text { gambar atau benda nyata ke } \\
\text { dalam matematika dan } \\
\text { menyelesaikannya }\end{array}$ & $71,87 \%$ \\
$\begin{array}{l}\text { Kemampuan mengekspresi- } \\
\text { kan peristiwa sehari-hari ke } \\
\text { dalam bahasa matematika }\end{array}$ & $46,87 \%$ \\
dan menyelesaikannya & \\
\hline
\end{tabular}

Berdasarkan Tabel 3, persentase pada indikator pertama yang diwakili soal 1 menunjukan bahwa kemampuan siswa dalam membaca representasi matematis dan menyelesaikannya adalah 64,06\%. Berdasarkan Tabel 2, kriteria pada indikator tersebut adalah sedang. Kemampuan siswa menyatakan gambar atau benda nyata ke dalam matematika dan menyelesaikannya pada soal 2 dengan persentase $71,87 \%$ berada pada kriteria tinggi. Dan kemampuan siswa mengekspresikan peristiwa sehari-hari ke dalam bahasa matematika dan menyelesaikannya pada soal 3 dengan persentase $46,87 \%$ dengan kriteria sedang. Berdasarkan hasil jawaban, masih banyak siswa yang menjawab soal dengan tidak tepat.

Adapun penelitian ini sejalan dengan penelitian yang dilakukan oleh (Septiani et al., 2020), (Saptika et al., 2018), dan (Aminah et al., 2018) bahwa siswa masih belum maksimal dalam mengerjakan soal kemampuan komunikasi matematik. Siswa masih melakukan kesalahan dalam menyelesaikan soal yang diberikan. Hasil penelitian yang dilakukan oleh (Aminah et al., 2018) menunjukkan bahwa tingkat kemampuan komunikasi matematis siswa pada proses pembelajaran yang menggunakan pendekatan saintifik tergolong dalam kategori sedang dan rendah.

Berikut akan dideskripsikan setiap kesalahan yang dilakukan siswa pada beberapa indikator.

a. Kesalahan pada indikator kemampuan membaca representasi matematis dan menyelesaikannya

Persentase yang diperoleh pada indikator kemampuan membaca representasi matematis dan menyelesaikannya adalah 64,06\%. Dari hasil ini dapat dikatakan bahwa kemampuan komunikasi siswa pada indikator ini adalah sedang. Berdasarkan hasil jawaban siswa, beberapa siswa sudah mampu membaca representasi matematis dan menyelesaikannya. Namun masih terdapat beberapa siswa yang melakukan kesalahan. Kesalahan yang dilakukan siswa dapat dilihat dari jawaban siswa pada Gambar 1.

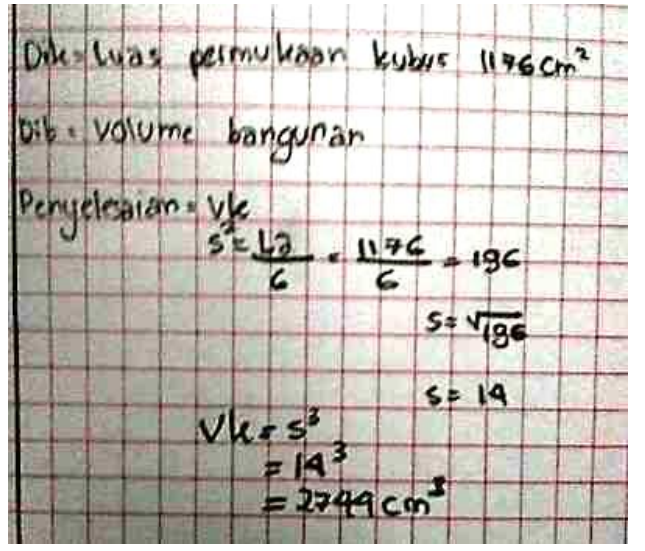

Gambar 1. Jawaban soal 1 (Sis-13)

Berdasarkan Gambar 1, terdapat kesalahan membaca (reading error). Kesalahan ini merupakan salah satu tipe kesalahan dari teori kesalahan Newman. Pada Soal 1, siswa mengalami kesalahan dalam memahami representasi gambar yang diberikan. Siswa tidak lengkap dalam menulis apa 
yang diketahui. Siswa hanya menuliskan luas dari permukaan kubus, sedangkan terdapat informasi mengenai tinggi dari limas dan kubus. Pada tahap penyelesaian, Siswa hanya dapat menyelesaikan sampai volume kubus. Hal ini dikarenakan siswa belum memahami representasi matematis yang termuat pada soal, sehingga siswa kesulitan dalam menyelesaikan permasalahan yang diberikan.

Masalah ini sejalan dengan penelitian yang dilakukan oleh (Mawaddah \& Mahmudi, 2021), kemampuan siswa dalam menulis matematis dan memahami ide dalam konteks tertentu masih rendah. Ketika siswa mampu memahami suatu permasalahan dalam konteks tertentu maka siswa tidak terpaku pada formula/rumus. Dengan pemahaman yang sudah ada, siswa akan bernalar untuk mencari solusi permasalahan lalu menyampaikannya kembali dalam bahasa matematis yang tepat.

b. Kesalahan pada indikator kemampuan menyatakan gambar atau benda nyata ke dalam matematika dan menyelesaikannya

Persentase yang diperoleh pada indikator kemampuan menyatakan gambar atau benda nyata ke dalam matematika dan menyelesaikannya adalah $71,87 \%$. Dari hasil ini dapat dikatakan bahwa kemampuan komunikasi siswa pada indikator ini berada pada kriteria tinggi. Berdasarkan hasil jawaban siswa, siswa sudah mampu menyatakan gambar ke dalam matematika dan menyelesaikannya. Hampir semua siswa dapat memahami permasalahan yang ditanyakan oleh soal. Siswa mampu menulis jawaban dengan prosedur penyelesaian yang sesuai dan jawabannya benar. Sehingga siswa dapat mengetahui langkahlangkah untuk dapat menyelesaikan permasalahan. Namun masih terdapat siswa yang melakukan kesalahan. Kesalahan yang dilakukan siswa ini dapat dilihat dari jawaban siswa yang disajikan pada Gambar 2.

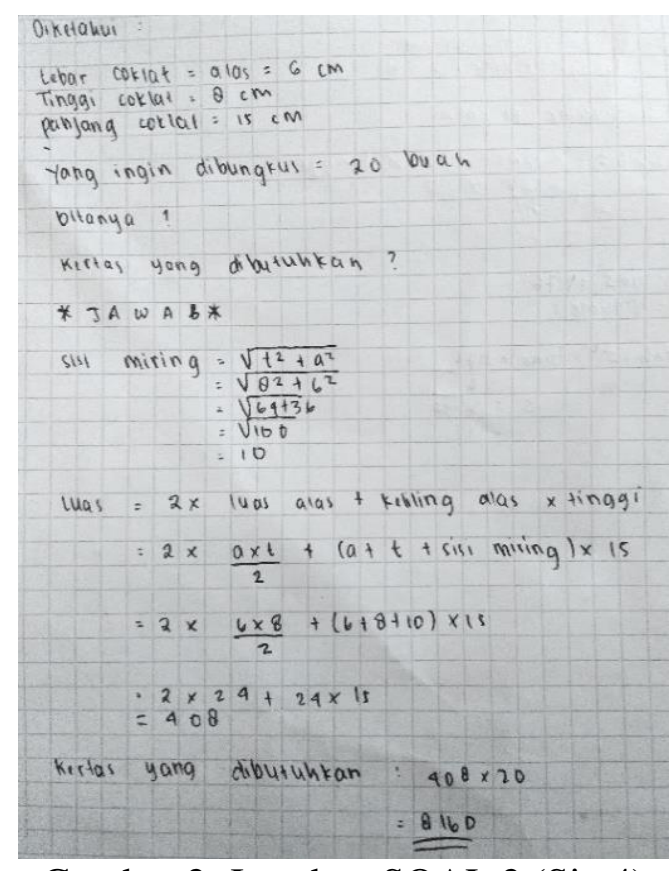

Gambar 2. Jawaban SOAL 2 (Sis-4)

Pada Gambar 2, terlihat bahwa siswa tidak memahami makna dari gambar. Siswa tidak bisa memahami yang mana alas dari lebar coklat yang diberikan, sehingga siswa kurang teliti dalam menentukan apa yang diketahui, hal ini mengakibatkan hasil dari penyelesaian salah. Siswa menuliskan lebar coklat sama dengan alas, dimana seharusnya alas dari prisma adalah $1 / 2$ dari lebar coklat. Kesalahan ini menyebabkan proses dan hasil akhir yang didapatkan oleh siswa tidak terselesaikan dengan benar.

Hal ini sejalan dengan penelitian yang dilakukan oleh (Niasih et al., 2019) bahwa kemampuan komunikasi matematika siswa masih termasuk kategori rendah, yang mana siswa 
kurang teliti dalam menjawab pertanyaan pada soal dan siswa tidak memperhatikan secara benar data yang diberikan. Hal ini menyebabkan siswa salah dalam menentukan hasil akhir dari soal yang diberikan.

c. Kesalahan pada indikator kemampuan mengekspresikan peristiwa sehari-hari ke dalam bahasa matematika dan menyelesaikannya.

Analisis kesalahan pada indikator kemampuan mengekspresikan peristiwa sehari-hari ke dalam bahasa matematika dan menyelesaikannya yaitu beberapa siswa mampu menulis yang diketahui, namun penyelesaian kurang tepat dan jawaban salah. Hal ini juga disebabkan karena siswa kurang menguasai konsep atau materi, sehingga siswa belum mampu menyelesaikan soal dengan tepat. Namun masih terdapat siswa yang tidak menuliskan apa yang diketahui dan ditanyakan dari soal yang diberikan. Indikator ini merupakan indikator yang memiliki persentase paling rendah dari indikator yang lainnya. Dapat dilihat dari persentase yang didapat pada indikator ini hanya 46,87\% yaitu berada dalam kategori sedang. Kesalahan yang dilakukan siswa pada indikator ini dapat dilihat pada Gambar 3.

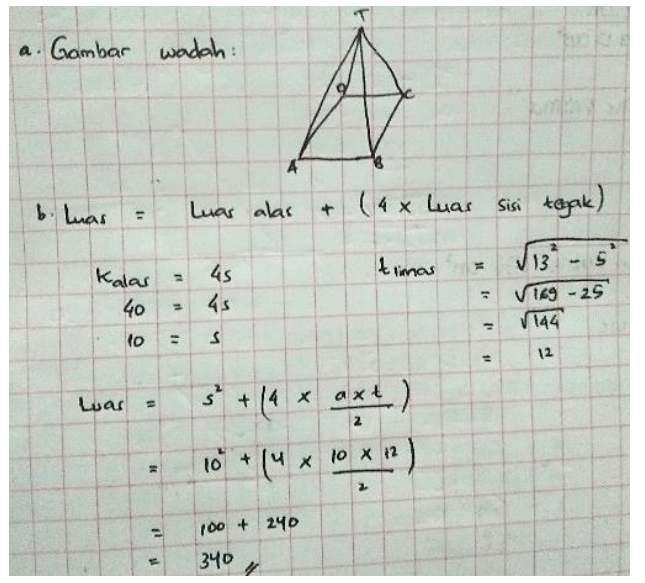

Gambar 3. Jawaban Soal 3 (Sis-3)
Pada Gambar 3 dapat dilihat bahwa siswa belum memiliki kemampuan literasi yang cukup. Pada tahap mengomunikasikan, siswa tidak menuliskan secara lengkap proses penyelesaian dalam bentuk matematis. Siswa tidak menuliskan informasi yang terdapat didalam soal. Siswa tidak menuliskan diketahui, ditanya dan jawab. Siswa langsung menuliskan jawaban dan menyelesaikan permasalahan yang diberikan. Siswa tidak menulis symbol/notasi matematika dengan baik. Siswa mampu melakukan proses penyelesaian dan hasil akhir yang diperoleh benar, namun proses yang dilakukan siswa tidak lengkap. Siswa juga tidak menuliskan secara lengkap satuan dari setiap besaran.

Hal ini sejalan dengan penelitian yang dilakukan oleh (Rahman et al., 2019) bahwa siswa tidak menuliskan apa yang diketahui dan ditanyakan. Siswa merasa bahwa dalam menuliskan apa yang diketahui ataupun ditanyakan merupakan sesuatu yang tidak terlalu penting sehingga siswa tidak menuliskan hal tersebut. Dalam penelitian yang dilakukan oleh (Utami et al., 2020) bahwa siswa belum mengetahui pentingnya mengerjakan matematika sesuai dengan alur ataupun sesuai konsep, sehingga yang terjadi adalah pandangan siswa hanya menuju ke hasil tanpa memperhatikan proses literasi matematika. Siswa menjadi terfokus pada rumus dan perhitungan yang harus dilakukan.

\section{KESIMPULAN DAN SARAN}

Berdasarkan hasil analisis data berupa hasil tes yang diberikan kepada siswa dapat ditarik kesimpulan bahwa kesalahan-kesalahan siswa dalam menyelesaikan soal-soal prisma dan limas yaitu (1) kesalahan dalam memahami representasi gambar; (2) 
kesalahan dalam memahami makna dari gambar; dan (3) kesalahan prosedur tidak tepat.

Berdasarkan hasil penelitian, dapat disampaikan saran untuk tenaga pengajar sebaiknya mengetahui mengenai kemampuan komunikasi matematika peserta didik. Komunikasi matematika siswa sangat penting dan perlu diperhatikan, agar siswa dapat memahami permasalahan matematika yang diberikan. Dalam hal ini yaitu mengenai kemampuan membaca representasi matematis dan menyelesaikannya, kemampuan menyatakan gambar atau benda nyata ke dalam matematika dan menyelesaikannya, dan kemampuan mengekspresikan peristiwa sehari-hari ke dalam bahasa matematika dan menyelesaikannya. Sebaiknya siswa SMP dilatih secara khusus mengenai kemampuan komunikasi matematis.

\section{DAFTAR PUSTAKA}

Aminah, S., Wijaya, T. T., \& Yuspriyati, D. (2018). Analisis Kemampuan Komunikasi Matematis Siswa Kelas VIII Pada Materi Himpunan. Journal Cendekia: Jurnal Pendidikan Matematika, 1(1), 15-22.

Arifin, Z., Trapsilasiwi, D., \& Fatahillah, A. (2016). Analisis Kemampuan Komunikasi Matematika Dalam Menyelesaikan Masalah Pada Pokok Bahasan Sistem Persamaan Linier Dua Variabel Siswa Kelas VIII-C SMP Nuris Jember. Jurnal Edukasi, 3(2), 9. https://doi.org/10.19184/jukasi.v3i 2.3522

Fadilah, \& Amalia, R. (2020). Analisis Kemampuan Komunikasi Matematis Mahasiswa Pendidikan Matematika Universitas Samudra pada Mata Kuliah Aljabar Linier. Seminar Nasional Peningkatan Mutu Pendidikan, 1(1), 555-558.

Lusiana, R., Susanti, V. D., \& Andari, T. (2019). Pengaruh Project Based Learning Berbasis Media Interaktif Terhadap Kemampuan Komunikasi Matematis.

AKSIOMA: Jurnal Program Studi Pendidikan Matematika, 8(3), 354-361.

https://doi.org/https://doi.org/10.24 127/ajpm.v8i3.2203

Mawaddah, S., \& Mahmudi, A. (2021). ANALISIS KEMAMPUAN KOMUNIKASI MATEMATIKA SISWA MELALUI PENGGUNAAN PROJECTBASED LEARNING TERINTEGRASI STEM. AKSIOMA: Jurnal Program Studi Pendidikan Matematika, 10(1), 167-182.

https://doi.org/https://doi.org/10.24 127/ajpm.v10i1.3179

Mustika, C. Z. (2018). Analisis Kemampuan Komunikasi Matematis Siswa MTs Dalam Menyelesaikan Soal Cerita Materi PSLV. Jurnal Pendidikan Tambusai, 2(6), 1719-1726.

Niasih, Romlah, S., \& Zhanty, L. S. (2019). Analisis Kemampuan Komunikasi Matematis Siswa SMP di Kota Cimahi Pada Materi Statistika. Jurnal Cendekia: Jurnal Pendidikan Matematika, 3(2), 266-277. https://doi.org/10.31004/cendekia. v3i2.107

Noor Ariani, D. (2017). Strategi Peningkatan Kemampuan Komunikasi Matematis Siswa SD/MI. MUALLIMUNA: Jurnal Madrasah Ibtidaiyah, 3(1), 96107.

Prentha, A., As'ari, A. R., Hidayanto, 
E., \& Nusantara, T. (2021). Peningkatan kemampuan komunikasi matematis tertulis melalui pendekatan Saintifik pada materi trigonometri bagi Siswa Kelas X MAN 1 Flores Timur. Aksioma: Jurnal Matematika Dan Pendidikan Matematika, 12(1), 69-79.

Rahman, I. H., Yassar, M. M., Fauziah, N. S., Rohmi, N., \& Sugilar, H. (2019). Analisis Kesalahan Dalam Menyelesaikan Soal Komunikasi Matematis Materi Bangun Ruang. Jurnal Perspektif, 3(1), 47-56. https://doi.org/10.15575/jp.v3i1.36

Rizta, A., \& Antari, L. (2018). Pengembangan Tes Kemampuan Komunikasi Matematis Pada Materi Sistem Persamaan Linear Untuk Mahasiswa Calon Guru Matematika. AKSIOMA: Jurnal Program Studi Pendidikan Matematika, $\quad 7(2), \quad 291$. https://doi.org/10.24127/ajpm.v7i2. 1525

Saptika, Y. A., Rosdiana, F., \& Sariningsih, R. (2018). Analisis Kesalahan Siswa Dalam Menyelesaikan Soal Kemampuan Komunikasi Matematis Pada Materi Bangun Datar. JPMI (Jurnal Pembelajaran Matematika Inovatif), $\quad 1(5), \quad 873$. https://doi.org/10.22460/jpmi.v1i5. p873-880

Septiani, D. T., Septian, A., \& Setiawan, E. (2020). Analisis Kesalahan Siswa Pada Kemampuan Komunikasi Matematis Dalam Pembelajaran Yang Menggunakan Pendekatan Saintifik. Jurnal Edukasi Dan Sains Matematika (JES-MAT), 6(2), 65. https://doi.org/10.25134/jesmat.v6i2.2832
Susanti, E., \& Ashari, M. (2019). Analisis Kemampuan Komunikasi Matematis Siswa Dalam Menyelesaikan Materi Fungsi Dengan Menggunakan Metode GASING (Gampang, Asyik, dan Menyenangkan). Seminar Nasional Matematika Dan Terapan, 1, 489492.

Syahrir, Kusnadin, \& Nurhayati. (2013). Analisis Kesulitan Pemahaman Konsep dan Prinsip Materi Pokok Dimensi Tiga Siswa Kelas XI SMK Keperawatan Yahya Bima. Jurnal Prisma Sains, 1(1), 88-102.

Utami, N., Sukestiyarno, Y. L., \& Hidayah, I. (2020). Kemampuan Literasi dalam Menyelesaikan Soal Cerita Siswa Kelas IX A. PRISMA, Prosiding Seminar Nasional Matematika, 3, 626-633. 